\title{
THE HUMAN POTENTIAL AND ITS ROLE IN BUSINESS DEVELOPMENT*
}

\author{
Raluca-Ana-Maria DUMITRU ${ }^{1}$ \\ ${ }^{1}$ Spiru Haret University, 13 Ion Ghica Street, Bucharest, 030045, Romania, \\ Tel.: +40214551000; Fax: +40213143900, Email: se_rdumitru@spiruharet.ro
}

\begin{abstract}
Through its object of activity, an economic organization has the role to efficiently use the means of production that it possesses in terms of the full utilization of the production capacities, of a high quality of the products and of obtaining profit.

Companies need their human, material, financial, informational resources etc., resources that they have at a certain moment in order to accomplish the mission and strategic objectives around which their entire activity revolves.

Although technical progress has substantially reduced man's presence in some production processes, no economic process has been noticed at any stage in the evolution of humanity that can replace by man's contribution. On the contrary, this involvement becomes more and more substantial, as man conceives and produces the productive apparatus necessary to meet his ever more diverse needs
\end{abstract}

Keywords: human potential; human resource; workforce; business; technical progress.

JEL Classification: $\mathrm{J}_{20}, \mathrm{~J}_{21}, \mathrm{~J}_{24}, \mathrm{~L}_{26}$

\section{Introduction}

Companies need in their human, material, financial, informational resources etc., resources that they have at a certain moment in order to accomplish the mission and strategic objectives around which their entire activity revolves.

${ }^{*}$ This article was presented at ICESBA 2017 (International Scientific Conference on Economic Sciences and Business Administration), Intercontinental Hotel, Bucharest, 24-25 of November 2017. 


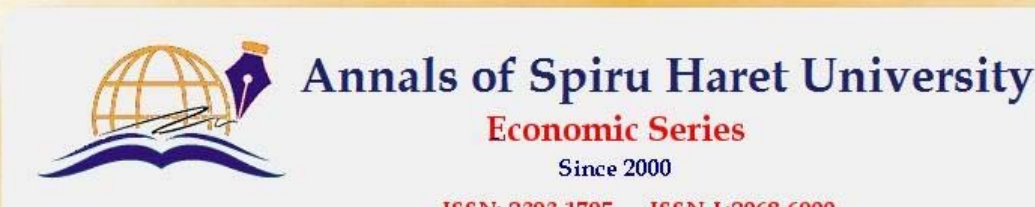

ISSN: 2393-1795 ISSN-L:2068-6900

Issue 4/2017

In order to truly appreciate a company, first of all we must know its potential, namely the human, material, financial, and other resources.

Through its object of activity, an economic organization has the role to use efficiently its means of production that it possesses, in terms of the most complete use of production capacities, a high quality of products and profit-making.

Although the technical progress has substantially reduced man's presence in some production processes, no economic process has been noticed at any stage in the evolution of humanity that can replace by man's contribution. On the contrary, this involvement becomes more and more substantial, as man conceives and produces the productive apparatus necessary to meet his ever more diverse needs.

\section{The human potential}

The notion of human potential has seen numerous and varied approaches. The concept of human potential is addressed at microeconomic level.

The workforce is the breathing, dynamic factor that puts, through work, the other factors into action, having a decisive role in the economic process. The study of the human resources at microeconomic level reflects labour as an active production factor; so, to characterize labour "it is necessary to highlight aspects such as: volume, structure, dynamics, movement and use of labour" [Isaic-Maniu et al., 1999].

In the paper Corporate Managerial Strategies [Nicolescu et al., 1998] the authors state that the human potential "is represented by the total number of employees that the company needs in order to carry out its activities. Besides employees - which are usually the basic human fund of the enterprise, the human potential also includes other members outside the unit, which through the board of directors, consultants or other forms use a part of the time budget for works and actions in the interest of the respective organizations".

At the microeconomic level, the main problems of the human potential analysis, as they are found in the specialty papers [Moroşan, 2008], are the following:

- the analysis of the size and structure of human resources;

- the analysis of human resource behaviour;

- analyzing the efficiency of human resource utilization.

The analysis of the size and structure of human resources pursues the quantitative and qualitative side of the economic organizations' framing with their staff, structure and size.

The quantitative analysis of the human resources highlights the human potential available to an economic agent and is expressed by number of employees indicator (scriptic number). This indicator characterizes the level of the human 


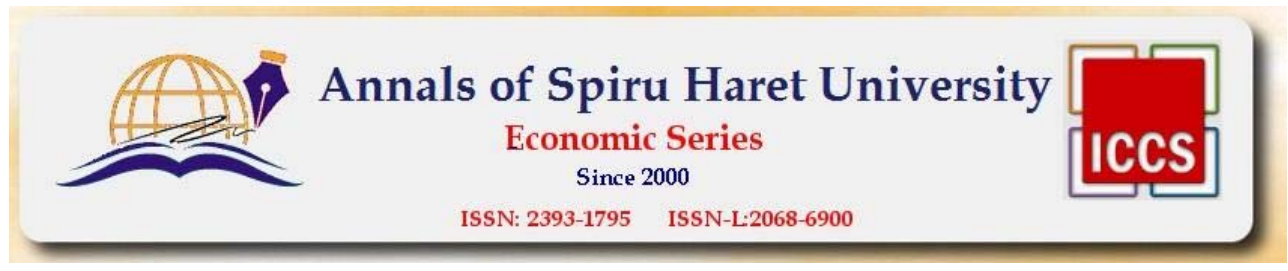

Issue $4 / 2017$

potential at a given time and consists of all the persons who have a contract of employment with the unit for which the calculation is made, whether they were present at work or absent for various reasons during the calculation period.

The human resources available to an economic organization can be interpreted in terms of indicators such as: the number of employees, the number of staff, the average number of employees, the average number of staff and the maximum permissible number of staff.

In analyzing the human potential the used indicators are the average number of employees and the average number of staff.

The qualitative analysis of human resources aims at the fact that the qualitative aspects of the human resource are reflected in the degree of qualification and have a particular importance for the companies.

In the literature, we find specific indicators for qualitative analysis of human resources such as:

a) the average qualification coefficient of the personnel;

b) the average complexity of the executed works.

The comparison of the two average coefficients (of the qualification and the complexity of the executed works) gives us the possibility to find out how to use the human resources from the point of view of the qualification, in the sense of a full concordance or of some discrepancies.

c) the average compliance coefficient reflects the reconciliation between the average worker qualification and the average job class.

The analysis of the human resources structure is grouped in: occupied personnel in industrial activities and personnel occupied in non-industrial activities.

At the level of the company, the classification of the personnel per occupation is carried out according to the Romanian Occupation Classification elaborated by the Ministry of Labour, Family and Social Protection together with the National Statistics Commission in 2011. The occupied personnel is divided into the following nine major groups [Order of the Minister of Labour, Family and Social Protection and of the President of the National Institute of Statistics no. 1832 of July $6^{\text {th }}, 2011$ regarding the approval of the Classification of Occupations in Romania - level of occupation (six characters), published in the Official Gazette of Romania no. 561 of August $\left.8^{\text {th }}, 2011\right]$ : members of the legislative body, the executive, senior public administration heads, senior officials and officials; specialists in various fields of activity; technicians and other technical specialists; administrative officials; service workers; skilled workers in agriculture, forestry and fishing; skilled and assimilated workers; plant and machine operators, machine and equipment assemblers; unqualified workers. 
Issue 4/2017

The staff of an economic organization can be grouped together by other characteristics: direct productive and indirect productive workers; technical staff: engineers, sub-engineers; staff with economic background; technical driving staff: foremen, technicians; management and administrative staff; general service personnel: service, guard, fire brigade or can be grouped on the basis of the following criteria: age (under 30 years, 31-40 years, 41-50 years, 51-60 years, over 60 years); seniority in the firm (1 year, 2 years, 3 years, etc.); gender; professional training; professional status (patron, employee, self-employed, etc.); functions of the firm (research and development, production, commercial, personnel, financial and accounting).

Staff grouping can be based on one or more features (age, level of training, profession, qualification, gender etc.).

The analysis of the human resources structure is done by reporting each category of personnel to the total staff (structural rates).

In the paper Statistical and Economic Analysis and Company Evaluation Methods, it is stated that "the structure of the workforce differs from one unit to another depending on its legal form, the ownership form and the type of main activity" [Vasilescu et al., 2002].

The human resources behaviour is analyzed from the perspective of employee mobility and stability and the use of working time.

The analysis of staff mobility and stability pursues the inputs and outflows of the personnel within the economic organization from normal causes (transfer, medical causes, studies, citizenship obligations, retirement, etc.).

Employees' fluctuation represents the outputs from the organization without the approval of the management or the termination of the employment contract; therefore, "the enterprises need to adopt a flexible system of ensuring the staffing needs both in terms of number and structure, which generates a process of the workforce movement".

In order to characterize the movement and fluctuation (mobility) of the staff, in the literature we can find indicators such as [Moroşan, 2008]:

a) the average staff input $\left(C_{i}\right)$ calculated as a ratio between the total number of personnel entries during the period (I) and the average number of $\operatorname{staff}\left(\mathrm{N}_{\mathrm{p}}\right)$;

b) the average output coefficient $\left(C_{e}\right)$ is determined as the ratio between the total number of personnel exits (for normal causes) during the period $(\mathrm{E})$ and the average number of staff $\left(\mathrm{N}_{\mathrm{p}}\right)$;

c) the coefficient of staff fluctuation $\left(C_{f}\right)$ established as the ratio between the total number of staff exits for unjustified reasons during the period $\left(\mathrm{E}_{\mathrm{N}}\right)$ and the average number of staff $\left(\mathrm{N}_{\mathrm{p}}\right)$. 
Issue 4/2017

The financial economic analysis based on these indicators is carried out in a dynamic period of 3-5 years to highlight trends of increase or decrease of staff movement and fluctuation.

The author Iosefina Moroșan considers that "the limitation of the fluctuation trend can generate the premises for increasing the stability of the personnel" [Moroşan, 2008] and uses for its sizing the following indicators:

a) share of seniority in the unit analyzed in total working time $\left(\mathrm{V}_{\mathrm{t}}\right)$;

b) the average seniority in the same unit is calculated as a weighted arithmetic mean according to the seniority of the employees in the unit $\left(\mathrm{t}_{\mathrm{i}}\right)$ and the number of employees having the same seniority $\left(\mathrm{N}_{\mathrm{i}}\right)$.

Changing average age $(\Delta \bar{T})$ is given to influence the structure of employees by age $\left(\Delta^{\bar{T}}\right)$ and the length of the same unit $\left(\Delta^{\Delta^{T}}\right)$ and calculated as the following:

$\Delta \bar{T}=\bar{T}_{1-} \bar{T}_{0}=\frac{\sum N_{1} t_{1}}{\sum N_{1}}-\frac{\sum N_{0} t_{0}}{\sum N_{0}}=\Delta_{g_{+}}^{\bar{T}} \Delta_{t}^{\bar{T}}$, where: $\Delta_{g}^{\Delta_{T}^{T}}=\frac{\sum N_{1} t_{0}}{\sum N_{1}}-\frac{\sum N_{0} t_{0}}{\sum N_{0}}$

and $\Delta_{t}^{\bar{T}}=\frac{\sum N_{1} t_{1}}{\sum N_{1}}-\frac{\sum N_{1} t_{0}}{\sum N_{1}}$

In analyzing the use of working time, it is necessary to state that "full use of working time is an important way of increasing the volume of production and increasing the efficiency of economic activity".

Therefore, the growth of an economic organization's performance can also be achieved by making optimum use of the working time.

The analysis of the use of working time aims at finding ways to increase the performance of the economic organization by fully using the working time and determining the economic repercussions that occur as a result of its irrational use.

Within the analysis, according to the literature [Isaic-Maniu et al., 1999], the indicators which are used there are the calendar time fund $\left(\mathrm{F}_{\mathrm{tc}}\right)$ and the maximum available time fund $\left(\mathrm{F}_{\mathrm{tmd}}\right)$.

The calendar time fund $\left(\mathrm{F}_{\mathrm{tc}}\right)$ is the product of the average number of employees $\left(\mathrm{N}_{\mathrm{s}}\right)$ and the number of calendar days of the analyzed period $\left(\mathrm{N}_{\mathrm{zc}}\right)$ when expressed in man/days. 


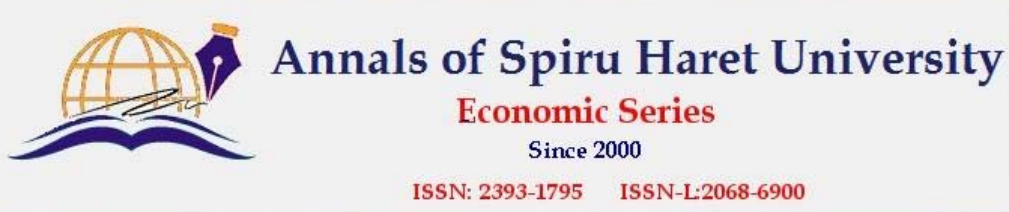

ISSN: 2393-1795 ISSN-L:2068-6900

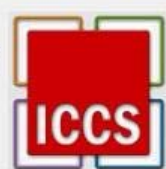

Issue 4/2017

The calendar time fund is also expressed in man-hours and is calculated as a product between the calendar time fund expressed in man-days and the normal working day of an employee expressed in hours/day.

The maximum available time fund $\left(\mathrm{F}_{\mathrm{tmd}}\right)$ is established as the difference between the calendar time fund and the time fund affected to weekly rest, legal holidays and rest leaves.

The author Iosefina Moroșan believes that "the maximum available time fund is the normal time resource that can be used within a calendar year. In the balance of working time, some losses from the maximum available time fund due to illnesses or other justified reasons are also considered" [Moroşan, 2008].

The structural analysis of the working time is done by weighting the working time in the total available maximum time fund (structural rates).

The maximum available time fund is obtained after the legal leaves of rest, holidays and free days have been deducted from the calendar time fund and this is the basic indicator of planning and analyzing working time.

The maximum available time fund consists of the two components: actual worked time (excluding extra worked time) and unused time for certain causes, namely:

- objective - one day breaks and within the shift, maternity leave, sick leave and part-time sickness, one day permissions and leaves and within the shift;

- subjective - the non-worked time for various other reasons.

The analysis looks at the evolution of the share of the actual time used in the maximum available time fund compared to the previous periods or with other units. Thus, the coefficient of the maximum fund available is calculated by reporting the time actually worked to the maximum available time fund.

This coefficient allows us to determine the amount of unused time in the maximum available time fund.

Within the financial economic analysis, a particular focus is on discovering the causes that determine the incomplete use of the maximum available time. This highlights the structure of unused time from objective and subjective causes. Increasing the share of the unused time from objective causes compared to the previous period and reducing the weight of non-motivated absences reflects positive aspects of a company's business

The analysis of the justified unused time's structure allows the adoption of the measures that are necessary to reduce the absences that are the causes of the 


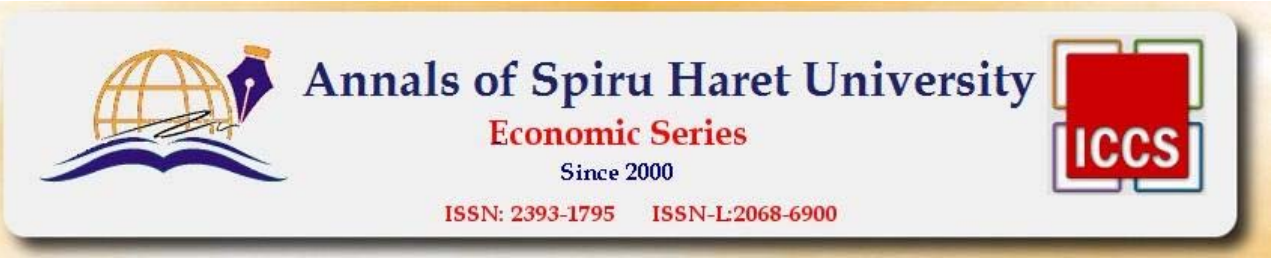

Issue 4/2017

actually used working time's reduction, with negative consequences on the volume of production.

The factorial analysis of the actual time used allows the discovery of the reserves to improve this indicator. In this respect, we start from the calculation model of the actual time indicator, expressed in man-hours, as follows [Moroşan, 2008]:

$$
\mathrm{T}=\mathrm{N} \times \mathrm{Z} \times \mathrm{h}
$$

where:

$\mathrm{Tl}$ - working time

$\mathrm{N}$ - the average number of workers in the script

$\mathrm{Z}$ - the average number of days worked per year by a worker

$\mathrm{h}$ - the average number of hours worked per day by a worker.

For example, if a company has 30 employees and an employee works 5 days / week, 8 hours / day, the working time is calculated as follows:

$$
\mathrm{Tl}=\mathrm{N} \times \mathrm{W} \times \mathrm{h}=30 \times 5 \times 8=1200
$$

Using the chain substitution method, the respective influences are determined. The average length of the year in days is obtained as the ratio between the actual worked time in man/days and the average number of workers in the script. The average duration of the working day in hours is established by reporting the actual time in man/hours to the actual time in man/days.

The analysis of using the working time would be irrelevant if its link with the production program would not be established. Thus, knowing the productivity of the planned hourly work, we can determine the production related to the non-working time.

In the literature, the static and dynamic analysis of the working time is done using the following indicators:

a) degree of scheduling the calendar time fund $\left(\mathrm{G}_{\mathrm{Ftc}}\right)$;

b) degree of using the calendar time fund $\left(\mathrm{G}_{\mathrm{uFtc}}\right)$;

c) degree of using the maximum available time fund $\left(\mathrm{G}_{\mathrm{uFtmd}}\right)$;

d) degree of non-using the maximum available time fund $\left(\mathrm{G}_{\mathrm{nt}}\right)$;

d) degree of using the average normal working day $\left(\mathrm{G}_{\mathrm{udmz}}\right)$.

In the paper Statistical and Economic Analysis and Company Evaluation Methods [Vasilescu et al., 2002], it is considered that "a constant concern of the decision-makers within the companies must be the promotion of an efficient 


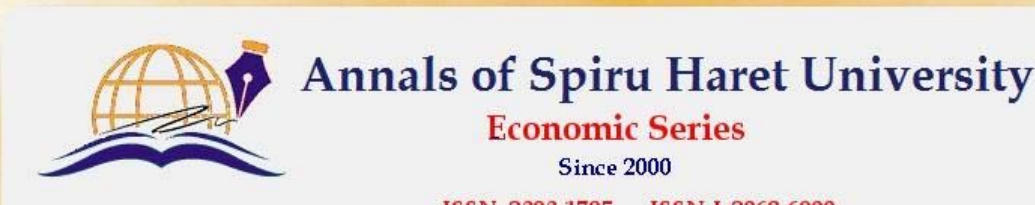

ISSN: 2393-1795 ISSN-L:2068-6900

Issue 4/2017

personnel policy which will result in maximizing the indicators of the amount of working time. This must be done not by increasing the number of staff employed, but by reducing the non-worked time, with favourable effects on the average duration of the working day and month, respectively the average actual time worked".

The effects of changing the working time - practical and theoretical aspects

Changing the working time has consequences on some economic and financial indicators related to the total time fund and to the average time per employee. The effects of changing the working time on the following economic and financial indicators are:

a) the value of the production obtained for sale;

b) the value of the exercise's production;

c) the volume of the turnover;

d) the added value;

e) the profit related to turnover;

f) the profit per employee.

The analysis of the human potential cannot be achieved without establishing the effective use of human resources.

The most important aspect of increasing employees' motivation is to emphasize their progress.

Basically nothing motivates more than the concept of progress. A steady stream of minor achievements brings more happiness than an occasional great success. This requires a constant flow of challenges, achievements and feedback, but dosed so that they do not reach any of the extremes of routine or overload.

In the paper Statistical and Economic Analysis and Company Evaluation Methods [Vasilescu et al., 2002], it is considered that "determining as accurately as possible the indicators that reflect the expense of working time for production must be a permanent concern of the decision-makers within companies".

The authors show that, in fact, "working time costs are the indicator of the effort used in calculating the level of labour productivity".

The human resource holds an important place in a company regardless of its object of activity. Motivation contributes to ensuring the balance of a psychomaterial nature. Self-esteem is developed as a result of the individual's stimulation, and the remuneration contributes to raising the individual's standard of living.

In order to be efficient, the employee must receive incentives both in the form of remuneration and of a psychological nature. A motivated man is the true 


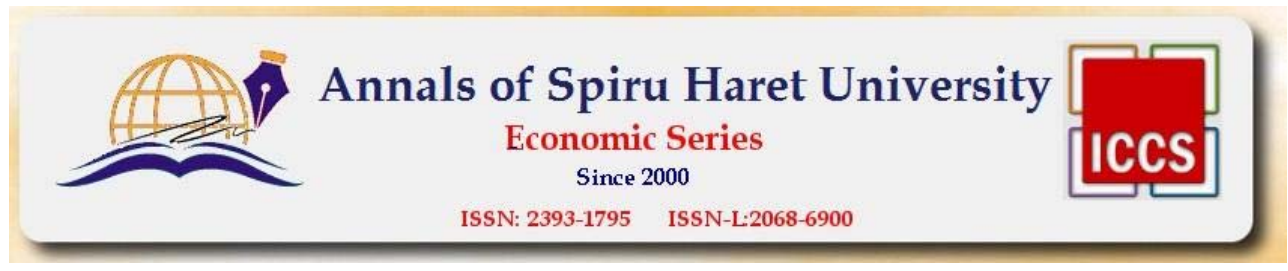

Issue 4/2017

value of the organization because it has a great interest in achieving the goals, while an unmotivated man has no concerns in this respect.

There are situations in which the manager is pressed by time and wanting to win a large number of clients does not take into account the wishes of the work resource, implicitly of the proper motivation, and the firm and the employee will suffer. The company will feel the lack of employee's performance, and the work resource will perceive work as a chore.

To understand the concept of motivation in work, we need to define it and identify the etymology. Many theorists and practitioners have been interested in studying work motivation under economic, but also psycho-social impact.

Motivation is a term borrowed from Latin and means "moving", "progressing", "acting". The motivation is given by all processes that have a psycho-material character and which determine the direction and persistence of the voluntary actions in order to achieve the objectives [Vagu \& Stegăroiu, 2006].

The goal of motivation should be to urge employees to stay within the company, to do everything they can to achieve performance for themselves and for the company they work for [Manolescu, 2001].

Motivation represents all the factors that contribute to stimulating the individual in order to achieve the results desired by the employee, but also by the manager. The human resources manager must continually seek to motivate the employee because he is the basis of any activity in the organization.

Motivation is the phenomenon to be studied according to the following levels [Frăţilă \& Duică, 2014]:

1) individual - knowledge and identification of the human resources' wishes;

2) organizational - developing and implementing strategies at the human resources department to stimulate employees.

The essential functions of motivation are [Stănciulescu, 2001]:

1) determination of action;

2) targeting the action;

3) the control and support of targeted behaviour in order to achieve the objectives.

As part of the employee motivation process, rewarding holds an important place. This represents the totality of the forms by which the human resource obtains a financial or non-financial income. The work resource benefits from rewards during the work contract, as long as is doing business in the company.

The most common rewarding form for an employee is the salary. The factors of influence in the salary sphere are as follows [Chivu, 2009]: 


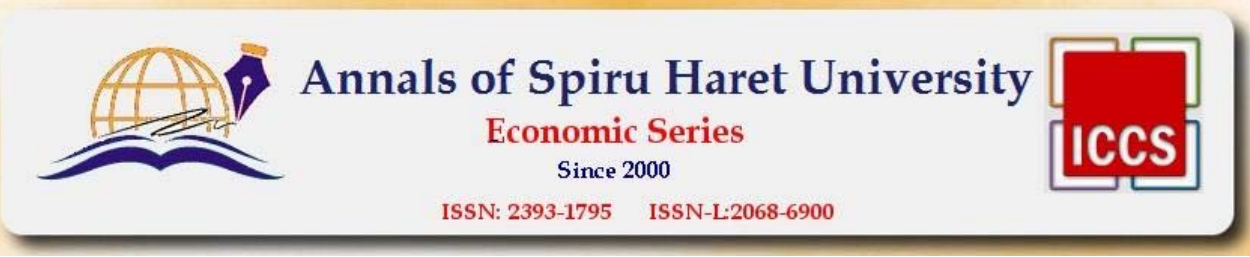

Issue 4/2017

1) trade union policies;

2) economic and social conditions;

3) labour legislation;

4) government policies;

5) business sector;

6) company size.

Other forms of rewards that a company's staff can benefit from are: meal vouchers, promotion, salary increases, bonuses granted for different occasions.

Employees want to be valued by the leadership team who must constantly seek to develop policies to ensure they are valued and rewarded for their results. Capitalizing the creative potential of the employee is based on non-discriminatory practices in the reward systems. People who are not attracted to the type of activity they carry are not seen as rare cases, but only the company suffers because it cannot stimulate the staff.

\section{The labour productivity}

Labour productivity and profit per employee determine the intensive use of the human resources that show the efficiency of resources' use.

The efficiency of labour expenditure is reflected by labour productivity.

Average labour productivity (physical or value) and marginal labour productivity are of interest in analyzing the efficiency of human resources utilization.

Iosefina Moroșan (2008) states that "the level of average labour productivity can be determined on the basis of several economic indicators, in the form of one of the following reports":

a. Production obtained for delivery / Total working time fund is the quantity or the value of the goods obtained in a unit of time or by an employee.

b. Total working time fund / Production obtained for delivery is the amount of time consumed for obtaining a good, performing a work or providing a service.

The labour productivity in industry, according to the methodology of the National Institute of Statistics and in accordance with the EUROSTAT requirements, is calculated as the ratio between the gross index of industrial production and the average number of employees in the industry. Industrial productivity indices are calculated per total industry, sections (mining, manufacturing, electricity, heating, gas, hot water and air conditioning) and per divisions CAEN Rev.2.

The average labour productivity is calculated both on the basis of the economic indicators expressed in physical units (pieces, tons, meters, etc.) and on the basis of the economic indicators expressed in terms of value (production of the exercise, 56 


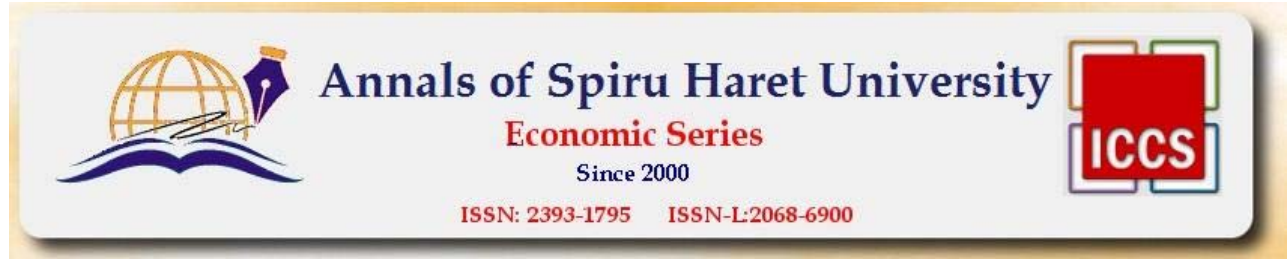

Issue $4 / 2017$

production obtained for delivery, added value, turnover, revenues from exploitation). It is thus possible to calculate the average physical labour productivity and the average value labour productivity.

The marginal productivity shows how much the manufactured production, the production of the financial exercise, the added value and the turnover increase by using an extra unit of working time.

Profit per employee is another indicator used to reflect the efficiency of human resources' usage.

\section{Conclusions}

Although the technical progress has substantially reduced man's presence in some production processes, no economic process has been noticed at any stage in the evolution of humanity in which man's contribution can be dispersed. On the contrary, this involvement becomes more and more substantial, as man conceives and produces the productive apparatus necessary to meet his ever more diverse needs.

The analysis of the human potential cannot be achieved without establishing the effective use of the human resources.

As part of the employee motivation process, rewarding holds an important place. This represents the totality of the forms by which the human resource obtains a financial or non-financial income. The work resource benefits from rewards during the work contract, as long as is doing business in the company.

The most common rewarding form for an employee is the salary. Other forms of rewards that a company's staff can benefit from are: meal vouchers, promotion, salary increases, bonuses granted for different occasions.

Employees want to be valued by the leadership team who must constantly seek to develop policies to ensure they are valued and rewarded for their results. Capitalizing the creative potential of the employee is based on non-discriminatory practices in the reward systems. People who are not attracted to the type of activity they carry are not seen as rare cases, but only the company suffers because it cannot stimulate the staff.

\section{References}

1. Anghel, I., Anica-Popa, A., Oancea Negescu, M. \& Popescu, A.M., Enterprise Evaluation (Bucharest: Economic Publishing House, 2010).

2. Bărbulescu, C. \& Dumitriu, N.A., Problems of Modern Management of Productive Enterprises (Bucharest: Economic Publishing House, 2010). 
Issue 4/2017

3. Chivu, I., Organizational Learning and Human Resources Development (Bucharest: ASE Publishing House, 2009).

4. Frăţ̧iă, C. \& Duică, M., Human Resources Management (Târgovişte: Bibliotheca Publishing House, 2014).

5. Ghic, G. \& Grigorescu, C.J., Financial Economic Analysis (Bucharest: Pro Universitaria Publishing House, 2012).

6. Hristea, A.M., Economic and Financial Analysis of the Business. From Intuition to Science, vol. $1 \& 2$ (second edition) (Bucharest: Economic Publishing House, 2015).

7. Isaic-Maniu, A., Mitruţ, C. \& Voineagu, V., Business Management Statistics, Second edition revised and added (Bucharest: Economic Publishing House, 1999).

8. Manolescu, A., Human Resource Management (Bucharest: Economic Publishing House, 2001).

9. Moroşan, I., Economic and Financial Analysis (Bucharest: Editura Fundației România de Mâine, 2008).

10. Moroşan, I., Economic and Financial Analysis (Bucharest: Editura Fundației România de Mâine, 2006).

11. Nicolescu, O. (coordinator), Corporate Management Strategies (Bucharest: Economic Publishing House, 1998).

12. Robu, V., Anghel, I. \& Șerban, E.C., Economic and Financial Analysis of the Firm (București: Editura Economică, 2014).

13. Spătaru, L., Economic and Financial Analysis: Enterprise Management Tool, $2^{\text {nd }}$ edition (Bucharest: Economic Publishing House, 2010).

14. Spătaru, L. \& Stancovici, A., Efficiency and Business Evaluation (Bucharest: Economic Publishing House, 2010).

15. Stănciulescu, G., Enterprise Economics (Bucharest: Oscar Print Publishing House, 2001).

16. Şuşu, Ş., Financial Economic Analysis (Suceava: "Ștefan cel Mare" University, 2016).

17. Vagu, P. \& Stegăroiu, I., Motivation in Work from Theory to Practice (Târgovişte: Bibliotheca Publishing House, 2006).

18. Vasilescu, Gh., Hurduzeu, M., Wagner, F., Niculescu-Aron, I.G. \& Zaharia, O., Statistical and Economic Analysis and Company Evaluation Methods (Bucharest: Didactic and Pedagogical Publishing House, 2002).

19. *** Law no. 85 of 5 April 2006 on insolvency proceedings, Official Gazette of Romania no. 359 of 21 April 2006.

20. *** Order of the Minister of Labour, Family and Social Protection and of the President of the National Institute of Statistics no. 1832 of July 6, 2011 regarding the approval of the Classification of Occupations in Romania - level of occupation (six characters), published in the Official Gazette of Romania no. 561 of August 8, 2011.

21.** Study of Human Resource Involvement in SMEs, 2016, http://www.businessvip.ro/?p=833. 